\title{
Creative Environment as a Factor of Professional Culture Formation of Journalists in the Digital Era
}

\author{
Oleshko Vladimir ${ }^{1}$, Oleshko Eugene ${ }^{2}$ \\ 'Ural Federal University, Ekaterinburg, Russia \\ ${ }^{2}$ Ural Federal University, Ekaterinburg, Russia \\ Corresponding author: Oleshko Vladimir, vladimir.oleshko@urfu.ru
}

\begin{abstract}
The article provides a systematic analysis of the creative environment formation of the leading actors in modern media societies using the example of a specific macro-region. According to the research, in the era of post-literacy and widespread digitalisation, systemic flaws in the organisation of dialogue between the authorities and the wider Russian population have become visible. By updating the tasks of improving media education and "accumulation" of digital capital, the authors offer the essential elements of a model for developing the creative environment for regional journalism.
\end{abstract}

Keywords: creativity, mass media, professional culture, digital capital, multimedia, model

\section{Introduction}

Creativity is most often seen as a general principle, an approach to solving problems that a person may face. In other words, as a personality trait and general ability to create. In this context, it is defined in correlation with the intellectual abilities of individuals (Frank Barron), the ability to find new ways of solving problems (Carl Ransom Rogers), to get rid of stereotypes (Joy Paul Guilford), to develop the creative personality as a whole permanently (Ellis Paul Torrance). Todd Lubart concludes: "Creativity is the property that sets us apart from other living things most, the ability that is the basis of human culture". [Lubart, 2009, 9]. Teresa M. Amabile, whose contribution to the field of creativity is considered innovative, has developed a three-component model that combines most of the characteristics and variables that lead to creativity described above. As a dominant component, she included an environment that can both encourage and hinder the development of these qualities in an individual or society. The practical implementation of this model, in her view, involves a case-by-case correlation between external and 
internal, where certain internal and external factors encourage an individual or, for example, individuals in the professional community, "to act at high levels of creative behaviour" [Amabile, 2012, 6].

It was this aspect that predetermined the authors' research into the creative environment of the leading actors in today's media community in an organisational context, which is not always in the focus of attention among philologists and culture specialists. At the same time, a grant from the Russian Science Foundation "Digitalization of communicative-cultural memory and problems of its intergenerational transmission" set out the main task of highlighting the factors contributing to the formation of a professional culture of journalists in the digital age. In general, the work aimed to define the vector of system development of regional mass media in the conditions of permanent social and technological transformations based on a model approach to this process, as well as to find solutions for the organisation of genuine dialogue relationships with the mass audience, contributing, among other things, to overcoming the digital generation gap as one of the most pressing problems of the present time [Gladkova, 2020].

\section{Research material}

\subsection{Study of the professional culture of journalists}

The structure of the professional culture of journalists as part of the general information culture of society traditionally has two dominant features that define the essence and main individual traits of its bearers: instrumental, differently — praxeological (professional skills and abilities) and mental (world outlook). "Praxeological side characterises how an entity of professional culture interacts with tools, instruments and objects of work, as well as the degree to which they are ready for a specific type of activity. The mental side is an integral characteristic of the collective and individual consciousness and self-consciousness of the subject of professional culture, and of the moral, philosophical and aesthetic prerequisites of activity" [Oleshko, 2020, 88]. In the digital age, unlike a period when only traditional media - periodicals, radio and television - prevailed, the professional culture of journalists "is seen in the context of uninterrupted processes of powerful media transformations with diverse and sometimes unpredictable consequences" [Professional culture of a journalist in the context of media transformations, 2020, 3]. 


\subsection{Process efficiency}

The latest practice shows that an ever-increasing number of media resources and actors in information activities (primarily bloggers and instagramers) are increasingly contributing to the development of communication strategies and tactics resulting from the attitude of turning various types of texts into only a well-selling product and meeting any, sometimes even asocial, needs of a mass audience. In turn, this provokes a devaluation of many social values or creates a kind of information consumerism, a purely consumerist ideology. In this context, as current sociological studies have shown [Vartanova, 2020], only professional journalists are capable of creating and systematically broadcasting texts of humanistic content, of forming the digital capital of society as a whole, and of ensuring "the existence of meaning in the contexts of the 'storage and distribution' of memory and its 'living meaning' and communication" [Piskoppel, 2020].

\subsection{Creative environment for the professional culture of journalists}

The dominance of digital media is now changing not only the global culture of the world community that has evolved over the decades but also social behaviour and everyday habits. The personal agenda is increasingly shaped by the individual through active interaction with an array of data, in either direct or hidden form, offered by both the media and a vast number of alternative sources. As the latest practice shows, in a competitive information environment, journalists' texts are not always a priority for audience representatives. Sometimes this is due to the low professional level of these authors and the noncreative approach to their work. It predetermines changes in the forms and methods of university education and the development of the system of professional development. However, in most cases, this is still because in the post-literacy era, defined as "the opportunity to develop socially and economically at the end of a formally organised educational process" [Communication trends in the post-literacy era: polylinguism and multiculturalism, 2017, 10], systemic flaws in the organisation of dialogue between the authorities and the wider Russian population have become evident, as demonstrated by the repeated rebirth of protest actions into asocial actions [Latov, 2017]. Traditional mass media, as the main information channel, according to the Russian Public Opinion Research Center, lose an audience annually [The era of digital media: paper vs screen, 2020]. Although new technologies now allow people not only to be involved in social networks in real-time, which is typical for young people but also to be involved in vari- 
ous social and cultural communities through the websites of the vast majority of the media. It also makes it possible to overcome generational inequality in general and to be integrated into the emerging digital culture, which allows a person not to become the object of manipulation and the consumer of fake information. However, all this is possible only if an individual has mastered at least the basics of media education [Sapunov, 2019] and media science [Astafyeva, 2013]. Civil society institutions, which are also called upon to activate this type of activity, are often sidelined. It is connected with their lack of coordination with each other and with authorities, with media and business. The role of the latter in the organisation of these processes became particularly visible during the Coronavirus Pandemic in 2020 when there was an urgent need for financial resources to organise widespread online information through the mass media, remote organisation of work and assistance in communicating with representatives of various societies.

Therefore, the creative environment of the professional culture of digital era journalists is not only a kind of media "thing-in-itself" (according to Immanuel Kant), including only the sphere of creating and broadcasting information products. With the help of the subjects of modern digital media culture, and the content they create, the state's current communication and information policy is determined in the current environment. It includes those aimed at "supporting offline and online activities of cultural, linguistic and ethnic groups" [Vartanova, 2020, 132], as well as all those that affect their intercultural communication and the processes of self-identification of individuals in the conditions of globalisation and permanent social and technological transformation of Russian society.

\subsection{The methodology of research}

The theoretical and methodological basis for the construction of our conception was provided by general and private scientific methods of theoretical and empirical levels of scientific knowledge. The systematic-cultural approach has predetermined the understanding of culture as a systematic whole that affects the functioning and evolutionary development of its specific subsystems and individual elements. In our case, the information culture, professional culture of journalists and mass media have been defined as the main broadcasters of current discursive practices in Russian society. Considering the multi-faceted nature of the creating problem and developing a creative environment, the authors were also based on an interdisciplinary and system-integrated approach that synthesises the ideas of philology, the theory of communication 
and cultural studies. In 2013-2019, 261 respondents from among journalists, top managers and media owners were interviewed by the method of interviews with the guide, and the content of 8 media in the Big Ural macro-region was monitored. Such an interdisciplinary vision of the declared problems and use of results of sociological research carried out by authors have allowed to reveal and describe the communicative and functional aspect of the given environment as creative in a set of various features contained in it.

The theoretical basis of the article was formed by the works mentioned above of scientists of Moscow State and Ural Federal Universities and actual works of foreign researchers. The trend is not only an increase in the number of works devoted to creativity, but also a change in their subject matter, highlighting the tendency to shift from descriptive to applied research [Williams, 2016] and, as regards mass media, from applied to predictive research [Dzyaloshinsky, 2017]. The evidence of the fact that cognitive factors associated with combining ideas from different cultures, including those broadcast through media texts, contribute to the development of liberal thinking [Cheng, 2012] has largely determined the importance of research into the role of new media in online discourse [Karasik, 2018]. Besides, in line with the tasks outlined in the latest research, we consider creativity with an emphasis on its human modality [Panizzon, 2019] and prove that the necessary changes should include increasing the technical accessibility of texts created by professional journalists, distributing media education programmes, and presenting more dialogue-oriented content in the digital environment. However, it is also necessary to take into account the fact that the current global trend is to increase the role of the state and public institutions in promoting these changes and thus helping to bridge the digital gap between generations [Digital Inequalities in the Global South', 2020].

\section{Results and discussions}

3.1. Description of the study

The interaction of professional culture and professional consciousness in the process of personal professionalisation is a two-way process. On the one hand, the professional culture of journalism emerges and develops based on the professional consciousness that is systematically formed by the social institution of journalism; on the other hand, it is itself a means of developing professional consciousness. Therefore, professional culture 
in this context can be seen as a kind of hierarchy of conscious meaning entities that make up the professional self-concept and ensure its self-regulation.

In the context of the development of a creative media environment, the main criterion for evaluating a journalist's professional culture are, obviously, the abilities, skills and ability of a person to use the whole range of resources of his or her consciousness, i.e. to attract knowledge, social experience, ideas, creative intuition for the prompt and creative solution of professional tasks.

Nevertheless, the development of the institute of journalism in the digital age has predetermined the formation of the consciousness of many of its subjects as "virtually oriented". Thus, it always included in the process of receiving information through new technologies or only from the global network. It is processing at various levels, its possible use or even its transmission after being rewritten as its own. While traditionally the professional consciousness of a person has been characterised in terms of readiness to solve urgent tasks of a psychological, gnoseological, axiological, emotional-voluntary, professional-creative nature, the factor of need for dialogue with its audience as pragmatically or economically conditioned by the format of modern mass media was most often formulated by our respondents as "professionally unconditional" ( $42 \%)$ or even "vital" ( $22 \%)$. Therefore, the implementation of the conceptual model of effective transmission of texts to the "digital" generation at various levels of media activity, which is the most relevant for practice today, should certainly involve both the formulation of forecast expectations for the technological development of these processes and the systematisation of the intentions of creative content and social coordination itself. This is what we have tried to achieve in our research.

3.2. The creative approach of the mass media to activities

in the context of digital transformation

The latest research today increasingly uses foresight as a tool to communicate people about their future as one of the most effective methods used to set priorities in social relations, economics, science and information technology. The defining factor, in this case, is the convention, where one does not just predict activities, defining the key players - science, business, universities, society, the state, but "using forecasting methods you agree on what future you want to build together" [Volokhina, 2019]. However, it is also essential to take into account the point of view of Manuel Castells, who emphasises in this approach that "the different technologies and business models 
supported by regulatory policies are causing different transformational trends in each of the communication system components" [Castells, 2017, 195].

Based on all the sociological material we have received and using the methodology described above as well, we have tried to develop, as we usually say today, a roadmap for implementing a strategy for the creative approach of the media to operating in a permanent digital environment. Its development highlights both the need for professional discourse on the boundaries of professionalism in modern journalism and the apparent contradictions in the development of the mass media under conditions of low demand for traditional media products by the "digital generation".

Multimedia, as the representation of different information formats in a single media source, has significantly transformed the typical and genre-forming features of media texts. Furthermore, while the operational information activities of the mass media under the new conditions have been studied quite systematically [Serdobinceva, 2019], the trends of the transformation of other genres require clarification. For example, not only traditional genres of journalism, but also new genres that emerge, quickly become outdated, become familiar and, for objective and subjective reasons, "concede" to others.

For example, longreads are almost entirely outdated due to the frequent mismatch between the time, creativity and material resources of journalists and the expected results. At the same time, storytellings are becoming increasingly popular today as a technique for dramatic and fascinating narration. This was due not only to its excellent correspondence with the thinking mechanisms of individuals who fully "use" the opportunities of the digital age, but also, to a large extent, to the desire to separate texts with a bright, creative solution from the information stream. The desire for dialogue with authors can also be explained by a large amount of audiovisual content, in particular podcasts, presented on the websites of modern mass media of various typological groups. The possibility of delayed (or "simultaneous" with other activities) listening/viewing illustrates this trend of media consumption which is gaining popularity with the audience. Collaboration with the author's reflection on facts, events or revealed phenomena, as well as the possibility of forming a "virtual and physical community around the editorial office" (Vasily Gatov's term) makes it possible to classify the genres and ways of media content broadcast based on these technologies, which have emerged recently, among the most popular in 2019-2020. This 
was particularly evident during the coronavirus pandemic (see, for example, https://www.proekt.media/article/podcast-vrachi-v-epitsentre-epidemii/).

The text monitoring also showed that during the period under review, one of the most popular genres for the audience was online reporting at the scene, which was broadcast directly on the media website. Two more modifications of this traditional genre were very popular with young people - a selfie-reportage of participants in real events and a reportage in the VR format (with the help of which a person becomes a subject in the system of mass communication, thanks to such techniques as 3D glasses, VR glasses, panoramic cameras shooting 360-degree video).

Creative solutions in the format of multimedia content always have two undeniable advantages over traditional texts - the effect of being present and the minimal time-consuming perception of it. Information products whose forms of existence are based on the natural character of perception (watching $\mathrm{TV}$ and video content, listening to audio) always have an advantage over those that require indirectness (searching, material and intellectual costs, comparing the views of different authors, highlighting the meaning). Recent practice shows, however, that each semiotic system, due to its structural characteristics, always imposes certain limitations on the values that it can convey, because when using only imaginative resources, for example, not everything that could be conveyed by the language through verbalised texts is read. This is particularly true in the process of journalists' creative work. Therefore, since in current conditions, it can be more correlated with the work of journalists, the issues of the professional culture of these subjects of information activities are becoming more relevant. Over the years of its existence and development, the social institution of journalism has developed a unique way not only to comprehend the world but also to implement productive, intentional practices as an essential instrument of direct democracy and civil society formation.

Thus, in modern science, the object of scientists' research paradigms is increasingly the contradiction between the need to adapt the human community to the "changing need of being" and the ability of a particular individual to master digital media practices [Sumskaya, 2019]. In other words, this problem actualises the study not only of the typological characteristics of the media audience but also of the information behaviour of individuals, which is reflected both in their desire to expand the number of forms and ways of organising their access to information sources and broadcasting channels and in the improvement of technologies for selecting texts, processing 
the information received and its further use, including for communicating with other people. At the same time, the creative environment of the professional culture of digital age journalists as mediators of these processes is the most important determinant of the meanings designed and broadcast by the media. This implies identifying its components for system analysis.

\subsection{Basis elements for the formation of a creative environment}

Any model is known to be a multi-factor formation, through which the development of the system's essential characteristics is predicted and, according to M. Vartofsky, "actions aimed at the future" are performed [Wartofsky, 2012, 64]. At the same time, we prove that the practical implementation of the conceptual model (in our case - not only the effective translation of texts at various levels of media activity in the Big Ural macro-region but also, in general, the formation of a creative environment), in addition to the creative itself, must include a social and administrative component.

Indeed, representatives of the media business occupy a central place in it, determining not only the vectors of development of specific media typologies but also their technological equipment. The whole complex of subjects included in the region's media community is also not just a dynamic, but also a rather crucial professional education distinguished by the diversity of types and directions of creative activity, as well as a social group that directly or indirectly determines the forms, nature and efficiency of management decisions in the sphere of economics, politics, culture and other areas of state construction and current life activities.

However, as recent research [Professional culture of a journalist in the context of media transformations. collective monograph, 2020] shows, the daily practice of the media in the region is most often identified with forms of mass public impact. Individual administrative or creative activities are hardly reflective of the authorities or the media business and are not identified with their professional culture. Furthermore, if this is the case, it is only due to acute conflict or crises, when public opinion associates the activities of a media outlet with its specific representatives or criminal acts against them (e.g., http://ura.ru/news/1052284754; and https://www. ural.kp.ru/daily/27104.7/4177496).

The regional specifics of the Big Ural macro-region and its adjacent territories are as follows: self-organisation of representatives of creative media professions and specialisations are either characterised by activities within creative unions - regional organisations of the Union of Journalists of the Russian 
Federation and the Media Union, or they are small in number as the guilds of economic observers, sports journalists, television reporters. The central cells of creative alliances organised in conjunction with the media are, as we have found, very amorphous in their activities. Formation and development of the professional culture of journalists in these conditions may well be a construction uniting various areas of activity in this area of mass media owners and employees, local organisations and organisational structures of regional creative unions, as well as government bodies interested in productive cooperation.

There is also a high demand for the implementation of social management initiatives through not only the practice of representing individual groups in social networks but also through a professional social or communication network specially created for this purpose. A prototype of this kind of self-governing social system in a region can be the Public Press Complaints Boards, which work in close cooperation with the regional boards of the Journalists' Union and the Media Audience Chambers. A system of cooperation agreements with the regional government, regional unions of industrialists and entrepreneurs, regional courts and several other organisations are seen as promising in this sense. However, as we have found out, interest in this type of cooperation is primarily shown by administrative staff, who thus solve pressing problems of financing the activities of journalists' organisations or purely image issues of public authorities.

Since the effective functioning of a state governed by the rule of law is to a large extent facilitated by citizen journalists, the development of professional culture among journalists in the area of systemic contacts with these subjects of information activity, and possibly the organisation of their training in the basics of systemic information activity, is also seen as one of the most promising areas. The contradictions that often arise today between professionals and the growing blogging community are often due to the latter's ignorance of the ethics of mass information relations or their elementary desire to collect as many "likes" as possible by any means. This is to a certain extent facilitated by competition for advertising revenue, in particular, the system of payment by commercial organisations and political-technological structures, which is gaining momentum in Russia, to the most successful subjects of information activity for placing contextual or hidden advertising on their pages in social networks.

On the whole, our analysis shows that weak signs of systematicity currently characterise the process of forming a professional culture of rep- 
resentatives of the media community in the Big Ural macro-region. This is primarily due to corporate closeness and, as we noted, a low degree of reflexivity. And not just for creative employees, but also for most representatives of the authorities and media business, who are also active in this creative environment. Thus, only self-organisation based on both the formation and functioning of specific structures and solidarity, traditions, universal but voluntarily accepted by the majority of the group of moral and ethical principles, as the approach, is mostly intended to characterise the options for creating fundamentally new forms of regulating relations in an increasingly globalised world and the emerging information society. At the same time, we are convinced that the system of higher education and training of media personnel of the new formation should also be an essential indicator of the effectiveness of this type of self-organisation.

Since the practical implementation of social and administrative planning in the implementation of the model approach in media activity is the least studied in media communications theory, as it is related to the development and introduction of several social technologies, at this stage of work we have so far only recorded as the basis for the model being developed the main elements of forming a creative environment for regional journalism of the digital era (Table 1).

\section{Conclusions of the study}

4.1. As the first systematic conclusion of the study, it can be stated that creativity in today's environment must be seen not only as a principle for solving the tasks that a person may face and the general ability to create but also as one of the factors forming the culture of society at one stage or another of its development. The connection between certain internal and external factors that encourage individuals or individuals in professional communities to "act at high levels of creative behaviour" therefore requires study and systematic analysis. This need was particularly evident in the context of globalisation, the permanent technological and social transformations that characterised the first decades of the 21 st century when virtually all civil society institutions were tasked with intensifying the organisation of dialogue between authorities, business and the general public in the legal states.

4.2. At the same time, the issues of forming and developing the creative environment of the leading actors of new media communities in the organisational context are not always in the focus of attention among philologists and 


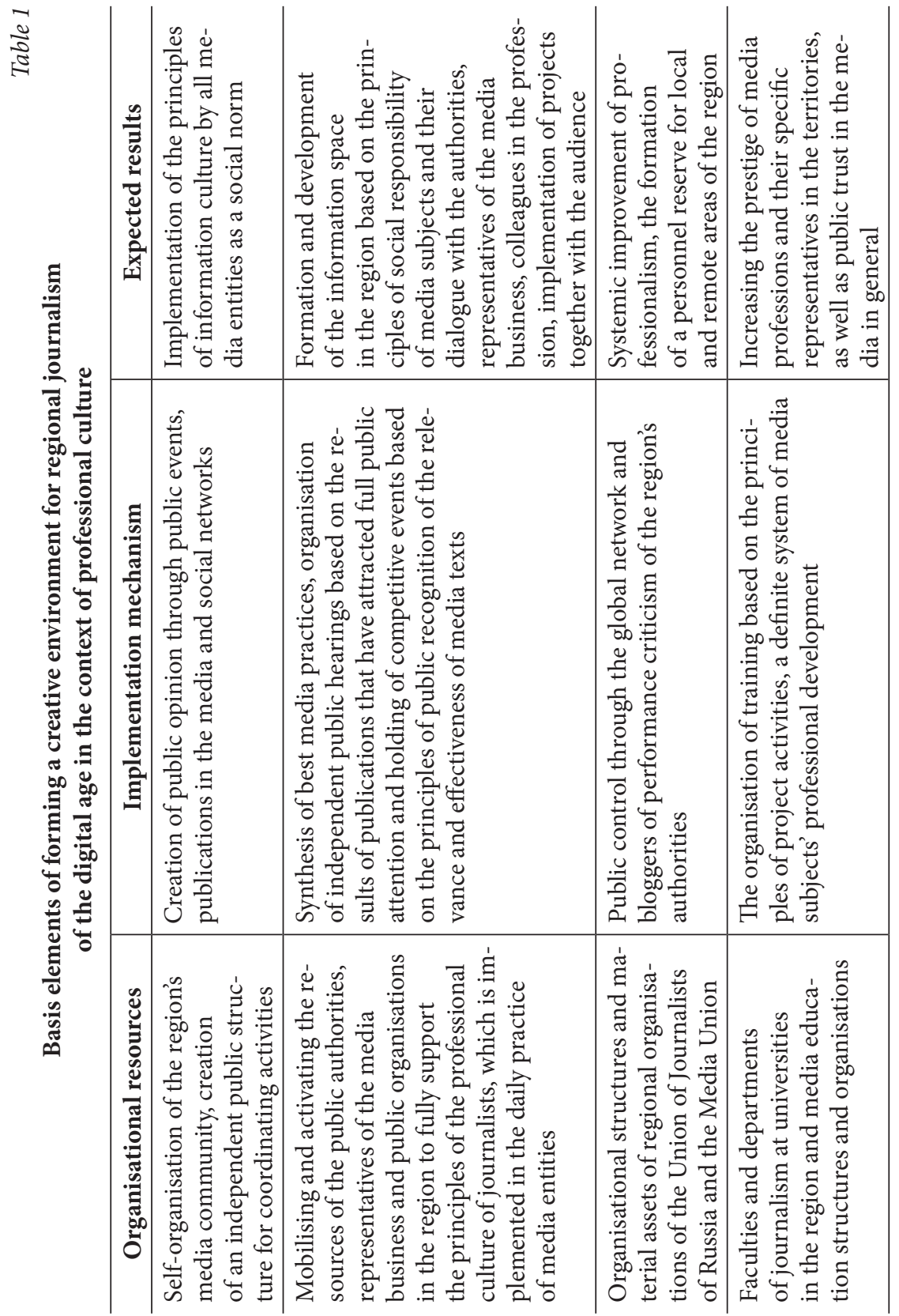


culture specialists. The latest practice shows that the ever-growing number of media resources and actors in information activities increasingly contributes to the development of communication strategies and tactics resulting from commercialisation attitudes and the satisfaction of any, sometimes even asocial, needs of the mass audience. Under these conditions, only professional journalists are most often able to create and systematically broadcast texts of humanistic content and, in general, to create digital capital in society.

4.3. In the era of post-literacy, systemic flaws in the organisation of dialogue between authorities and the wider Russian population became evident, as evidenced by the fact that protest actions have been repeatedly reborn into asocial actions not only in Russia but also abroad. This is mainly due to the contradictions that characterise the digital generation divide and the loss of audiences to traditional mass media as the main channels of information and education. At the same time, new technologies and a creative approach to the genre transformation of content today give people not only the opportunity to be included in real-time in the information agenda but also the involvement of the vast majority of the media in various social and cultural communities through websites. In general, this makes it possible to overcome generational inequality and to be integrated into the digital culture that is being shaped, allowing a person not to be manipulated and not to be a consumer of fairy information. However, all this is possible only if an individual learns at least the basics of media education and mediaology.

4.4. The analysis carried out by the authors has shown that weak signs of consistency characterise the process of forming the professional culture of representatives of the media community of the Big Ural macro-region. As the survey of respondents has proved, this is primarily due to corporate closeness and low degree of reflexivity. It is not only right for creative employees in the media, but also for the majority of government representatives and the media business, who actively influence this environment, which by default should be creative. The formation of fundamentally new ways of regulating relations in the emerging information society predetermines the development and implementation of social and managerial planning within the framework of a model approach to the organisation of media activities. Since this is connected, with the development and implementation of several social technologies, the authors at this stage of the study have fixed the main elements of forming a creative environment for regional journalism in the digital age as the basis for the model being developed. It includes 
organisational resources, implementation mechanisms and expected results, which are detailed and presented in the form of a table.

\section{Funding}

The study was carried out with the financial support of the grant of the Russian Science Foundation No. 19-18-00264 in the framework of the scientific project "Digitalization of communicative-cultural memory and problems of its intergenerational transmission".

\section{Acknowledgement}

The authors would like to thank their colleagues for their contribution and support to the research. They are also thankful to all the reviewers who gave their valuable inputs to the manuscript and helped in completing the paper.

\section{Conflict of Interest}

The authors have no conflict of interest to declare.

\section{References:}

1. T. Lubart, F. Zenasni, S. Tordjman, K. Mushiru. Psychology of creativity. Moscow (2009).

2. M. Teresa Amabile. Componential theory of creativity. Working Paper, Harvard business school, 12-096, April 26 (2012).

3. A. A. Gladkova, M. Ragnedda. Exploring digital inequalities in Russia: An interregional comparative analysis. Emerald Group Publishing Ltd. (UK), T. 44, No. 4 (2020), pp. 767-786. https://doi.org/10.1108/OIR-04-2019-0121.

4. V.F. Oleshko. Psychology of journalism. Theory and practice. Moscow (2020)

5. Professional'naya kul'tura zhurnalista v kontekste transformatsii SMI. Kollectivnaya monografia, gl. red M. A. Myasnikova [Professional culture of a journalist in the context of media transformations. collective monograph, by ed. M. A. Myasnikova]. Ekaterinburg (2020).

6. E. Vartanova, A. Gladkova. Digital divide and digital capital in multiethnic Russian society. Journal of Multicultural Discourses, Vol. 15, Issue 2 (2020), pp. 126-147. https://doi.org/10.1080/17447143.2020.1745212.

7. A. A. Piskoppel. Pamyat I kultura cherez prizmu ponyatii "kommunikatsiya" I "translyatsiya" [Memory and culture through the prism of the concepts of "communication" and "translation"] (2020). https://psyhoinfo.ru/nauka-istoriya-metodologiya/pamyat-i-kultura-cherez-prizmu-ponyatii-kommunikatsiya-i-translyatsii. 
8. Kommunikatsionnyye tendentsii v epokhu postgramotnosti: mnogoyazychiye i mul'tikul'turalizm [Communication trends in the post-literacy era: polylinguism and multiculturalism]. Ekaterinburg (2017).

9. Yu. V. Latov. Protestnyye nastroyeniya i protestnyye deystviya rossiyan [Protest moods and protest actions of Russians]. Sociologicheskaya nauka i socialnaya practica, T. 5, no. 1 (2017), pp. 49-69. DOI: 10.19181/snsp. 2017.5.1.4992.

10. Epokha tsifrovykh media: bumaga vs ekran. [The era of digital media: paper vs screen] (2020). URL: https://wciom.ru/index.php?id=236\&uid=116624.

11. V.I. Sapunov, V.N. Dorokhin. Aktualizatsiya zashchitnykh teoriy mediaobrazovaniya v "epokhu postpravdy" informatsionnogo obshchestva. [Actualization of protective theories of media education in the "post-truth era" of the information society]. Znak: problemnoye pole mediaobrazovaniya, no. 2 (32) (2019), pp. 47-52.

12. O.N. Astafyeva. Medialogiya kak sintez nauk: izmeneniye sotsiokul'turnoy real'nosti v ob"yektive [Medialogy as a synthesis of Sciences: changing socio-cultural reality in the lens] Culturologicheskiy journal, no. 1 (11) (2013), pp. 11-21.

13. R. Williams, M. A. Runco, E. Berlow. Mapping the themes, impact, and cohesion of creativity research over the last 25 years. Creativity Research Journal, Vol. 28, no. 4 (2016), pp. 385-394. doi:10.1080/10400419.2016.1230358.

14. I. M. Dzyaloshinsky, A. V. Sharikov. O sovremennom sostoyanii i dal'neyshem razvitii sfery kommunikatsionnykh nauk v Rossii [About the current state and further development of the sphere of communication Sciences in Russia]. Mediascope, Release 3 (2017). http: www.mediascope.ru/2342.

15. C. Y. Cheng, A. K. Leung. Revisiting the multicultural experience-creativity link: The effects of perceived cultural distance and comparison mind-set. Social Psychological \& Personality Science, Vol. 4, no. 4 (2012), pp. 475-482. doi: 10.1177/1948550612462413.

16. V.I. Karasik. Tvorchestvo v setevom diskurse [Creatives in network discourse]. Vestnik Moskovskogo gosudarstvennogo oblastnogo universiteta, Serija: Lingvistika, 5 [Bulletin of the Moscow State Regional University, Series: Linguistics, 5] (2018), pp. 29-44. doi: 10.18384/2310-712X-2018-5-29-44.

17. M. Panizzon, P. Fernando, P. Barcellos. A three-level process for assessing cultural readiness for strategic foresight projects. World Futures Review, Vol. 11 (2019), pp 331-350. doi:10.1177/19467567198621155.

18. Digital Inequalities in the Global South'. Palgrave Macmillan Ltd, Basingstoke, England (2020). ISBN 978-3-030-32706-4.

19. A. Volokhina. Kak futuristy predskazyvayut budushcheye. Interv'yu s Aleksandrom Chulokom, zamestitelem direktora Forsayt-tsentra VSHE. [How futurists 
predict the future. Interview with Alexander Chulok, Deputy Director of the HSE foresight center] (2019). http://radiovesti.ru/audio/279/373.mp3.

20. M. Castells. Sila obshcheniya [The Power of communication]. Moscow (2017).

21. E. N. Serdobinceva. Informatsionnyye zhanry v publitsisticheskikh tekstakh [Information genres in journalistic texts]. Penza (2019).

22. A. S. Sumskaya, S. A. Sverdlov. "Analogovoye" i "tsifrovoye" pokoleniye mediaauditorii: rol' kommunikativnoy i kul'turnoy pamyati $\mathrm{v}$ transformatsii media-praktik ["Analog" and "digital" generation of media audience: the role of communicative and cultural memory in the transformation of media practices]. Izvestija Ural'skogo federal'nogo universiteta, Serija 1: Problemy obrazovanija, nauki i kul'tury. Vol. 25, no.3 (189) (2019), pp. 32-48.

23. M. W. Wartofsky. Models: Representation and Scientific Understanding. Springer Science \& Business Media (2012).

DOI 10.15826/B978-5-7996-3081-2.40

\section{Media Globalisation and Desacralisation of a Journalist's Image}

\section{Antonova Natalya ${ }^{1}$, Khafizova Viktoria ${ }^{2}$, Gurarii Anna ${ }^{3}$}

${ }^{1}$ Ural Federal University, Ekaterinburg, Russian Federation

${ }^{2}$ Ural Federal University, Ekaterinburg, Russian Federation

${ }^{3}$ Ural Federal University, Ekaterinburg, Russian Federation

Corresponding author: Gurarii Anna, anna.gurariy@urfu.ru

Abstract. The media is becoming the main source of information about the surrounding reality in the digital environment. In fact, they shape the reality. They become a powerful instrument of influencing mass consciousness through symbols and values. The media industry, information consumption practices as well as the role of a journalist are changing in the context of new media. The results of the survey $(n=750)$ have shown that the younger generation trusts information posted on social networks and does not distinguish the professional work of a journalist from the activities of bloggers and citizen 